\title{
New reports of rust fungi (Uredinales) from Sharan (Kaghan Valley), Pakistan
}

\author{
Afshan $\mathrm{NS}^{1^{*}}$, Khalid $\mathrm{AN}^{2}$ and Niazi $\mathrm{AR}^{2}$ \\ ${ }^{1 *}$ Centre for Undergraduate Studies, University of the Punjab, Quaid-e-Azam Campus, Lahore, 54590, Pakistan, \\ pakrust@gmail.com \\ ${ }^{2}$ Department of Botany, University of the Punjab, Quaid-e-Azam Campus, Lahore, 54590, Pakistan, \\ drankhalid@gmail.com
}

Afshan NS, Khalid AN, Niazi AR 2015 - New reports of rust fungi (Uredinales) from Sharan (Kaghan Valley), Pakistan. Plant Pathology \& Quarantine 5(2), 35-42, Doi 10.5943/ppq/5/2/1

\begin{abstract}
During a survey of rust fungi of Sharan, Kaghan Valley, Puccinia tsinlingensis on Elymus semicostatus was collected and is described as a new record for Pakistan. Pucciniastrum agrimoniae, Melampsora populina subsp. populina and Puccinia coronata var. himalensis are reported as new records for Sharan (Kaghan Valley). Agrimonia eupatoria, Populus alba and Sporobolus coromandelianus are reported as new host plants from Pakistan for Pucciniastrum agrimoniae, Melampsora populina subsp. populina and Puccinia coronata var. himalensis, respectively. Previously, about 93 species of rust fungi were known from Kaghan Valley with only 28 rust taxa from Sharan. This study has raised the number of reported rust taxa of Sharan to 32.
\end{abstract}

Key words - Forests - Mansehra - new records - Populus caspica

\section{Introduction}

The Kaghan Valley, north-east of Mansehra District of the Khyber Pakhtunkhwa Province of Pakistan, is bounded on the east and southern side by Azad Jammu Kashmir, on the north by Chilas and Gilgit agencies and on the west by Allai Kohistan and Mansehra. The valley extends $155 \mathrm{~km}$, rising from an elevation of $650 \mathrm{~m}$ to its highest point, the Babusar Pass, at 4,170 m (Abbasi 1993). The forests are situated in the middle of Kaghan, occupying the lower parts and are situated at varying altitudes between 1370 metres to 3660 metres (Iqbal 1986).

According to standard classification of "Forest types of Pakistan"(Champion et al. 1965), the Kaghan Valley forests fall under the major type 'Montane Temperate Forests' and 'Himalayan Dry Temperate Forests'. The Kaghan Valley, of which the forests are an essential part, has great recreational attraction. Sharan in middle of Manshi forest, located $16 \mathrm{~km}$ north of ParasinKaghan Valley (Mansehra) is a less commonly known attraction of the valley and is part of the mountain range with Musa KaMusalla as its peak at 4075.79 meters. The area around Sharan has been classified into two different forest zones called as darshi and manshi. Sharan forest is the most dense and thick forest in Pakistan. It is home to a variety of flora and fauna. In Sharan, Abies pindrow Royle locally known as "Rewar" is generally available as pure crop at varying altitude from 2130 to 3190 meters and with spruce, Picea smithiana Boiss., locally called "Kachhal" at lower elevation. The broad leaved trees include Juglans regia L., Aesculus indica (Wall. ex 
Jacquem.) Hook.f., Acer caesium (Reinw. ex Blume) Kosterm., Prunuscomuta, Populus spp. and Taxus wallichiana Zucc. The undergrowth is usually of Vibernum spp., Skimmia laureola (DC.) Decne., Indigoferaspp., Spiraea spp., Rubus spp., Berberis spp. and Lonicera spp. The herbaceous flora consists of Valeriana wallichii DC., Viola spp., Paeonia emodi Wall., Fragaria spp., Bergenia spp., Atropa acuminate Royle ex Lindl., Aconitum spp. and Primula spp. (Iqbal 1986). Although this floristically rich area has many host plants, it is uredinologically very poorly explored. Uptil now, about 93 species of rust fungi are known from Kaghan Valley with only 28 rust taxa from Sharan (Ahmad et al. 1997, Iqbal et al. 2008, Afshan et al. 2010). During the present study, five host plants infected with rust fungi were collected from Sharan, Kaghan Valley. Among these, one rust species, Puccinia tsinlingensis is newly recorded from Pakistan, while remaining three species are additions to the rust flora of Sharan, Kaghan valley. This study has raised the number of reported rust taxa of Sharan and ultimately of Pakistan.

\section{Materials \& Methods}

Freehand sections of infected tissue and spores were mounted in lactophenol and gently heated to boiling point. The preparations were observed under a NIKON YS 100 microscope and photographed with a digipro-Labomed and a JSM5910 scanning electron microscope. Drawings of spores and paraphyses were made using a Camera Lucida (Ernst LeitzWetzlar, Germany). Spore dimensions were taken by an ocular micrometer. At least 25 spores were measured for each spore stage. The rusted specimens have been deposited in the herbarium of the Botany Department, at the University of the Punjab, Lahore (LAH).

\section{Results}

Puccinia tsinlingensis Y.C. Wang, Actaphytotax. sin.10: 296 (1965)

(Figs. 1-2)

Spermogonia and Aecia unknown. Uredinia amphigenous, subepidermal, yellowish brown to dark brown, $0.09-0.1 \times 0.1-4.0 \mathrm{~mm}$. Urediniospores redinglobose to subglobose or ovoid to ellipsoid, $18-21 \times 20-24 \mu \mathrm{m}$ (mean $19.7 \times 22.00 \mu \mathrm{m}$ ); wall 1-1.5 $\mu \mathrm{m}$ thick, pale brown to cinnamonbrown, echinulate; germ pores $2-5$, scattered, obscure; pedicel hyaline, $4-5 \mu \mathrm{m}$ wide and up to 30 $\mu \mathrm{m}$ long. Telia amphigenous, covered by the epidermis, dark brown to blackish brown, loculate, with paraphyses, $0.09-0.5 \times 0.2-0.8 \mathrm{~mm}$. Teliospores oblong to clavate or ellipsoid, $13-21 \times 32-49 \mu \mathrm{m}$ (mean $16.00 \times 40.1 \mu \mathrm{m}$ ); wall 1.5-2 $\mu \mathrm{m}$ thick, cinnamon-brown to chestnut brown but paler basally, smooth; apex mostly truncate, sometimes rounded or conical to obliquely conical, 4-6 $\mu \mathrm{m}$ thick; germ pores obscure; pedicel hyaline to light brown, 5-7 × 4-10 $\mu \mathrm{m}$.

Known distribution - widespread in China on different species of Bromus (Cao \& Zhaung 2000, Zhuang 2005).

Material examined - Pakistan, Khyber Pakhtunkhwa (KP), Sharan, 2752 m a.s.1., 27 July 2007, on Elymussemicostatus (Nees ex Steud.) Melderis (= Agropyron striatumNees ex Steud.), N.S. Afshan, NSA \# 102. (LAH Herbarium No. NSA 1086).

Comments - Puccinia tsinlingensis is previously reported on Bromus japonicas Thunb. And B. tectorum L. from China (Cummins 1971, Cao \& Zhuang 2000, Zhuang 2005). Puccinia tsinlingensis is reported from Pakistan as a new record for this country.

Pucciniastrum agrimoniae (DC.) Tranzschel, Scripta Bot. Horti Univ. Imper. Petrop.4: 301 (1895)

(Figs. 2-3)

Telia not found. Uredinia hypophyllous, covered by the epidermis, scattered, irregular or rounded, pulverulent, yellow to yellowish orange, minute, $0.1-0.3 \times 0.2-0.4 \mathrm{~mm}$, opening by a central pore; peridia hemispherical; peridial cell irregularly polygonal to rectangular in shape, smooth; ostiolar cells subglobose to ovoid or oblong. Urediniospores globose to subglobose or ovoid to ellipsoid, $12-18 \times 15-25 \mu \mathrm{m}$ (mean $15.20 \times 20.00 \mu \mathrm{m}$ ), wall $1-1.5 \mu \mathrm{m}$ thick, echinulate, hyaline to light yellow; germ pores $4-6$, scattered, obscure. 
Known distribution - cosmopolitan, reported on different species of Agrimonia (Far \& Rossman 2014).

Material examined - Pakistan, Khyber Pakhtunkhwa (KP), Sharan, 2752 m a.s.1., 28 July 2007, on Agrimoniaeupatoria L, with II stage, N.S.Afshan, NSA \# 104. (LAH Herbarium No. NSA 1102).

Comments - Pucciniastrum agrimoniae has been reported on Agrimonia aitchisonii Schönb.Tem. From Hazara (Malik \& Khan 1944, Ahmad 1956a, b) and from Leepa Valley (AJ \& K) by Saba et al. (2013). It is a new report from Sharan (Kaghan Valley). Agrimonia eupatoriais also a new host plant for this fungus from Pakistan.

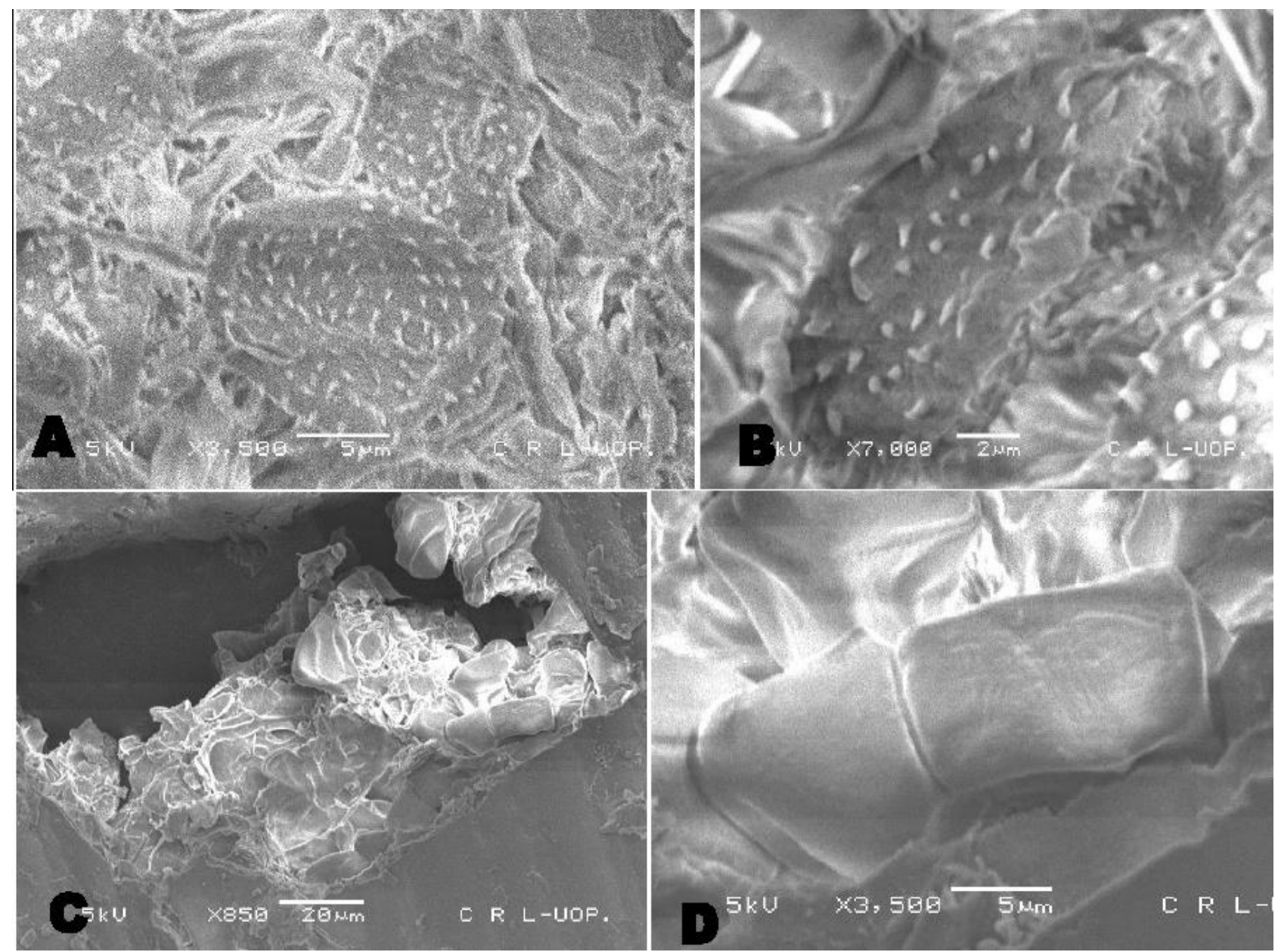

Fig. 1 - Puccinia tsinlingensis. A, Scanning electron micrograph of urediniospores showing wall ornamentation. B, A closer view of echinulate urediniospore. C, SEM photograph of a telium. D, A smooth-walled teliospore. This picture is copyright of Najam-ul-SeharAfshan.

Uromyces vossiae Barcl. J. Asiat. Soc. Bengal 59: 76 (1890)

(Fig. 4)

Spermogonia and Aecia unknown. Uredinia hypophyllous, dark brown, sori $0.2-0.4 \times 0.09$ $0.1 \mathrm{~mm}$. Urediniospores globose to subglobose or ovoid, $18-24 \times 20-27 \mu \mathrm{m}$, (mean $21.00 \times 23.5$ $\mu \mathrm{m}$ ); wall $0.7-3.5 \mu \mathrm{m}$ thick, densely verrucose or striolate verrucose, light yellow to brown; germ pores 2-3, 2 equatorial or supra-equatorial with 1 apical; paraphyses clavate, $6-8.5 \mu \mathrm{m}$ wide and up to $55 \mu \mathrm{m}$ long. Telia black, scattered, amphigenous, sori $0.1-0.2 \times 0.05-0.1 \mathrm{~mm}$. Teliospores dark brown to cinnamon-brown, $18-27 \times 21-35 \mu \mathrm{m}$ (mean $22.5 \times 28.0 \mu \mathrm{m}$ ), ovoid to ellipsoid, minutely verrucose, mostly at the apex, wall $1-3 \mu \mathrm{m}$ thick at sides, 4-9 $\mu \mathrm{m}$ thick apically; germ pore 1 , equatorial. Pedicel long, hyaline, persistent, $6-7 \mu \mathrm{m}$ wide and up to $90 \mu \mathrm{m}$ long.

Known distribution - reported on several taxa of Poaceae from India and Pakistan (Cummins 1961, Ramachar \& Cummins 1963, Afshan \& Khalid 2013). 
Material examined - Pakistan, Khyber Pakhtunkhwa (KP), Sharan, 2752 m a.s.1., 27 July 2007, on Phacelurus speciosus (Steud.) C.E. Hubbard, with II, III stages, N.S. Afshan, NSA \# 84 (LAH Herbarium No. NSA 1113).

Comments - Uromyces vossiae has been reported on Phacelurus speciosus from Kaghan by Ahmad (1962, 1969), Khanspur by Afshan et al. (2008) and Afshan \& Khalid (2013), and from Leepa Valley (AJ \& K) and Fairy Meadows by Saba et al. (2011, 2013).
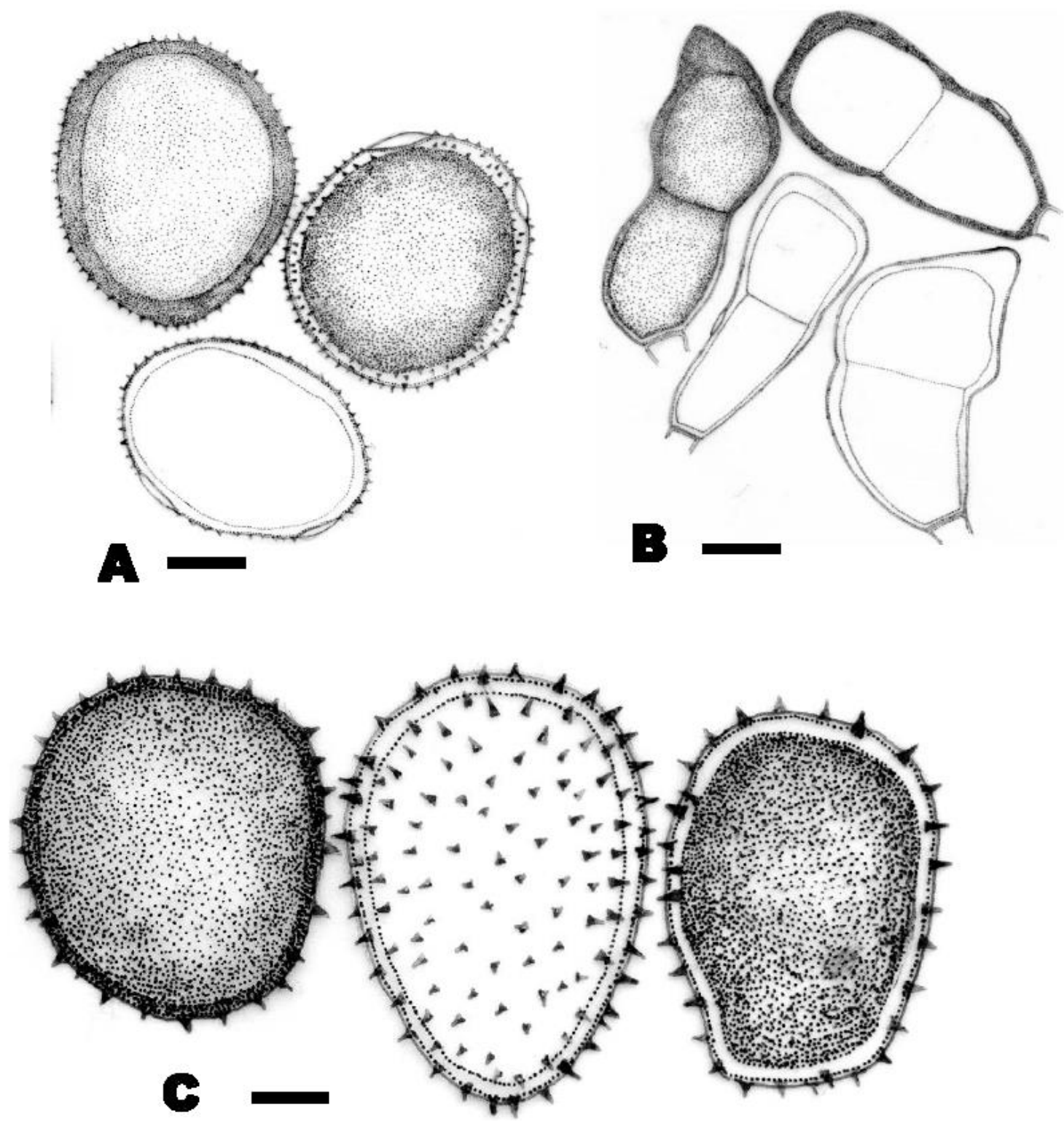

Fig. 2 - Camera lucida drawings. A, Urediniospores of Puccinia tsinlingensis showing echinulate wall ornamentation. B, Teliospores. C, Urediniospores of Pucciniastrum agrimoniae. - Bars $=10 \mu \mathrm{m}$. This picture is copyright of Najam-ul-SeharAfshan. 


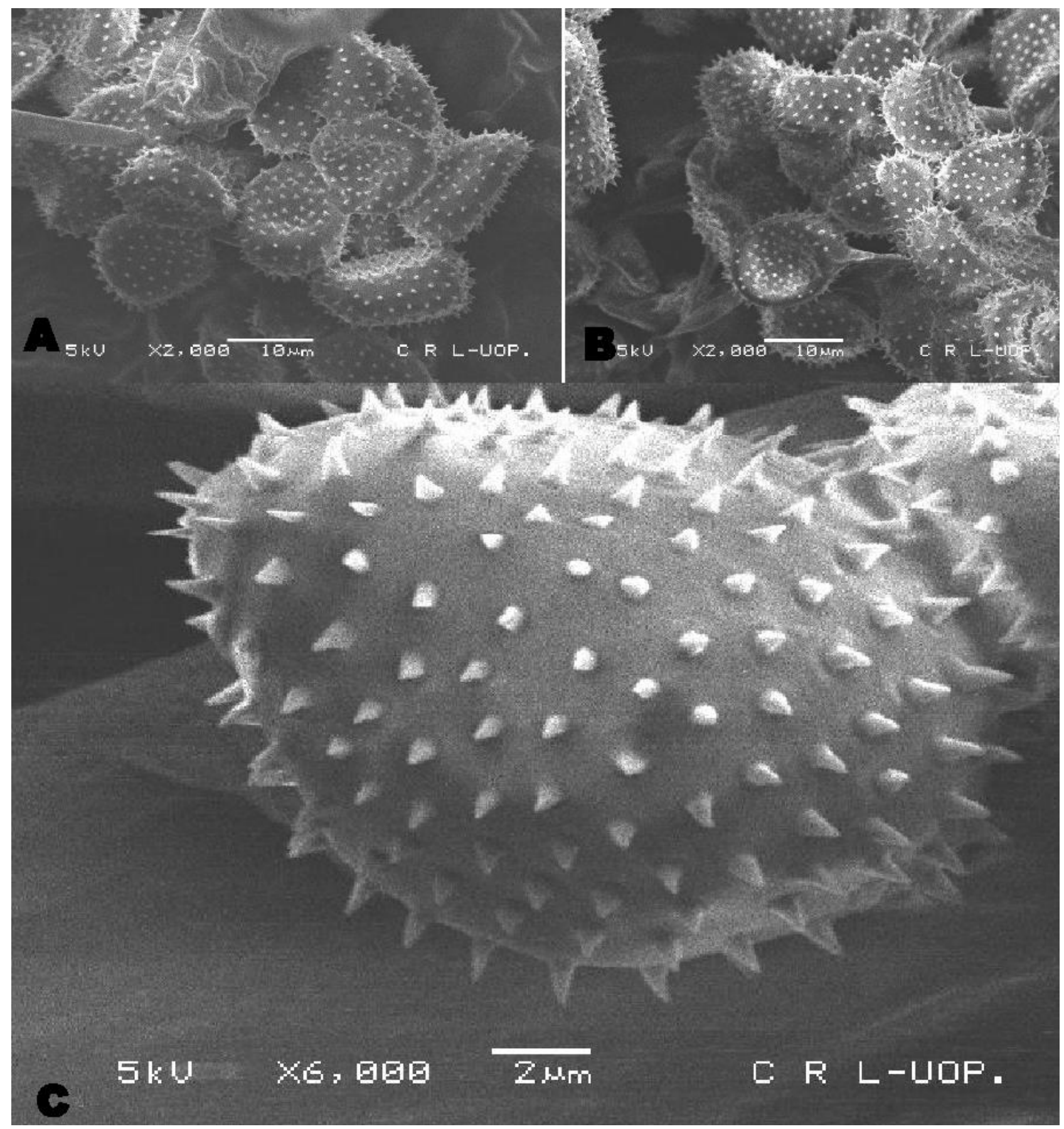

Fig. 3 - Pucciniastrum agrimoniae. A, B SEM photographs of urediniospores. C, SEM of a urediniospore showing echinulate wall ornamentation. This picture is copyright of Najam-ulSeharAfshan.

Melampsora populina subsp. populina (Jacq.) Lév., Annls Sci. Nat., Bot., sér. 38: 375 (1847)

Spermogonia, Aecia and Telia unknown. Uredosori hypophyllous, in little groups, 0.07-0.1 $\times 0.1-0.4 \mathrm{~mm}$, minute, pulverulent, yellow to yellowish orange, rounded, at first covered by the raised epidermis, distributed over the whole leaf surface. Urediniospores ovoid to obovoid or ellipsoid to broadly ellipsoid, hyaline to light yellow, 13-20 × (16-) 18-27 $\mu \mathrm{m}$ (mean $16.7 \times 22.4$ $\mu \mathrm{m})$, wall 1-2 $\mu \mathrm{m}$ thick, echinulate; germ pores obscure; pedicel hyaline, short; paraphyses clavate to capitate, hyaline to pale yellow, 15-20 × 45-60 $\mu \mathrm{m}$, wall thick, up to $10 \mu \mathrm{m}$ at the apex and $4 \mu \mathrm{m}$ thick at the sides. 
Known distribution - reported on different species of Populus from Italy, Spain, Chile, USSR, Portugal, Norway, Scotland and Pakistan (Farr \& Rossman 2013).

Material examined - On Populusalba L., Pakistan, Khyber Pakhtunkhwa (KP), Sharan, 2752 m a.s.1., 27 July 2007, N.S. Afshan, NSA \# 79. (LAH Herbarium No. NSA 1019).

Comments - Melampsora populina (Pers.) Karst. (= M. decidioides (DC.) Shroet.) has previously been reported on Populus caspica (Bornm.) Bornm. from Quetta, Parachinar and Abbottabad (Ahmad et al. 1997). Melampsora populina subsp. populina is a new record from Sharan (KP). Populus alba is also a new host for this rust fungus from Pakistan.
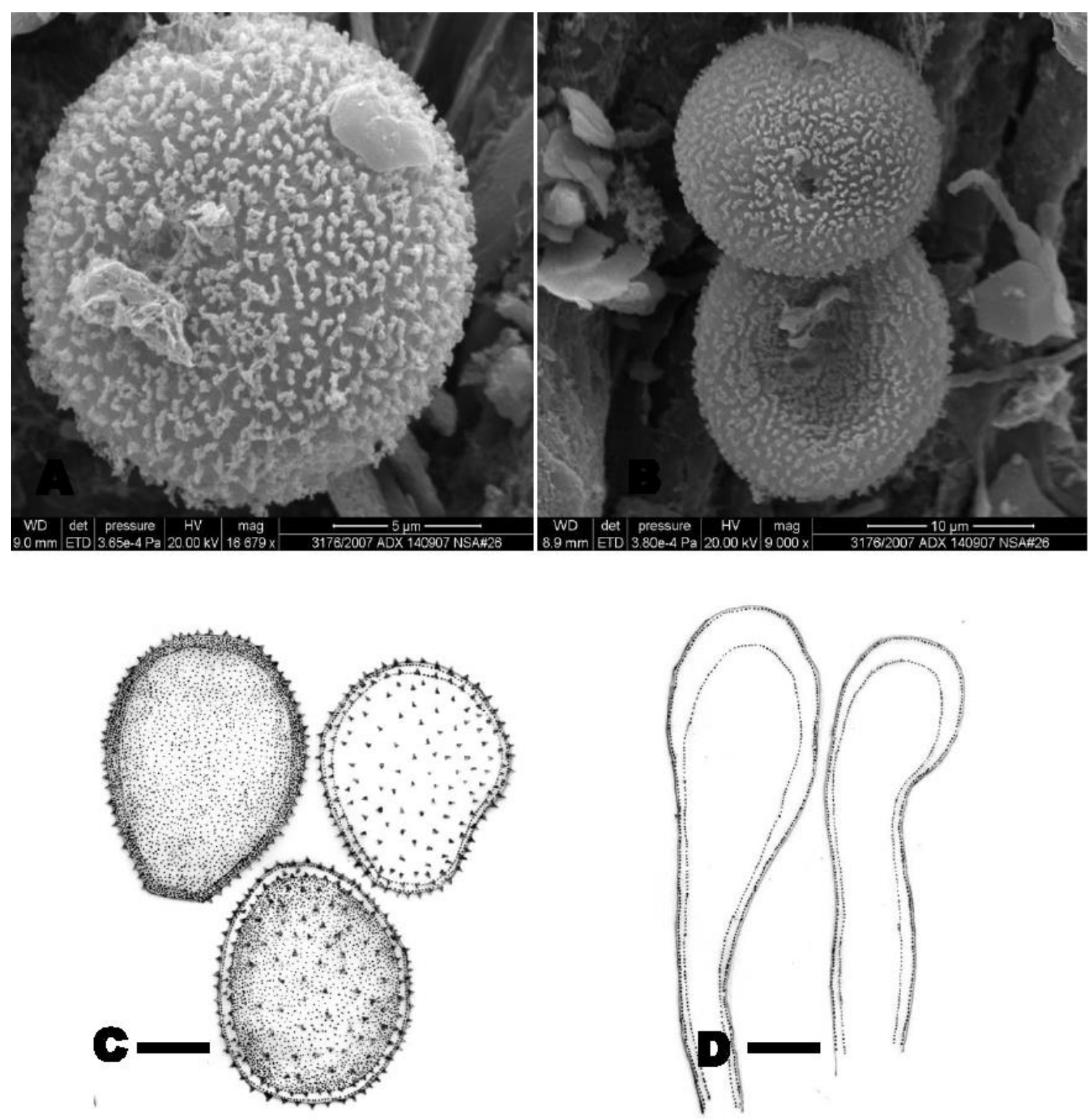

Fig. 4 - A, BSEM photographs of urediniospores of Uromycesvossiae. C, D Camera lucida drawings of urediniospores and capitate paraphyses of Melampsora populina subsp. populina. Bars $C \& D=10 \mu \mathrm{m}$. This picture is copyright of Najam-ul-SeharAfshan.

Puccinia coronata var. himalensis Barclay Trans. Linn. Soc. London, 3: 227 (1891)

(Fig. 5)

Spermogonia and Aecia unknown. Uredinia amphigenous, brown, 0.07-0.09 $\times 0.1-0.3 \mathrm{~mm}$. Urediniospores globose-subglobose or ovoid, 14-19 × 16-21 $\mu \mathrm{m}$ (mean $16.5 \times 19.00 \mu \mathrm{m}$ ); germ pores $2-6$, scattered, obscure; wall $1.5-2 \mu \mathrm{m}$ thick, pale yellow to nearly colorless, echinulate; 
pedicel minute, deciduous; paraphyses clavate, apex $12-13 \mu \mathrm{m}$ wide, $7-9 \mu \mathrm{m}$ thick below, up to 50 $\mu \mathrm{m}$ long. Telia amphigenous, long covered by the epidermis, blackish brown, sori $0.06-0.08 \times$ 0.09-0.2 mm. Teliospores golden to brown, paler basally, 14-19 × 27-47 $\mu \mathrm{m}$ (mean $16.5 \times 37.00$ $\mu \mathrm{m}$ ), wall up to $2 \mu \mathrm{m}$ thick at sides, $2-5 \mu \mathrm{m}$ thick apically excluding digitations, apex coronate, with digitations 8-17 $\mu \mathrm{m}$ long; pedicel short, yellowish brown to brown, 8-9 $\times 9-15 \mu \mathrm{m}$.

Known distribution - world-wide, mostly present in Europe, Asia, North America (Mexico). Common aecial hosts are Rhamnus spp. (Rhamnaceae) with various grass genera (Poaceae) as telial hosts (Hiratsuka et al. 1992, Liu \& Hambleton 2012, Afshan \& Khalid 2013).

Material examined - On Sporobolus coromandelianus (Retz.) Kunth, with II, III stages, Pakistan, Khyber Pakhtunkhwa (KP), Sharan, at 2752 m a.s.1., 26 July 2007. N.S. Afshan, NSA \# 101. (LAH Herbarium No. NSA 1048).

Comments - Puccinia coronata var. himalensis has been previously reported on Piptatherum vicarium (Grigorj.) Roshev. From Neelum Valley (AJ \& K), Pakistan by Afshan et al. (2010). It is a new record for Sharan (KP) and Sporobolus coromandelianusis also a new host for $P$. coronata species complex from Pakistan.

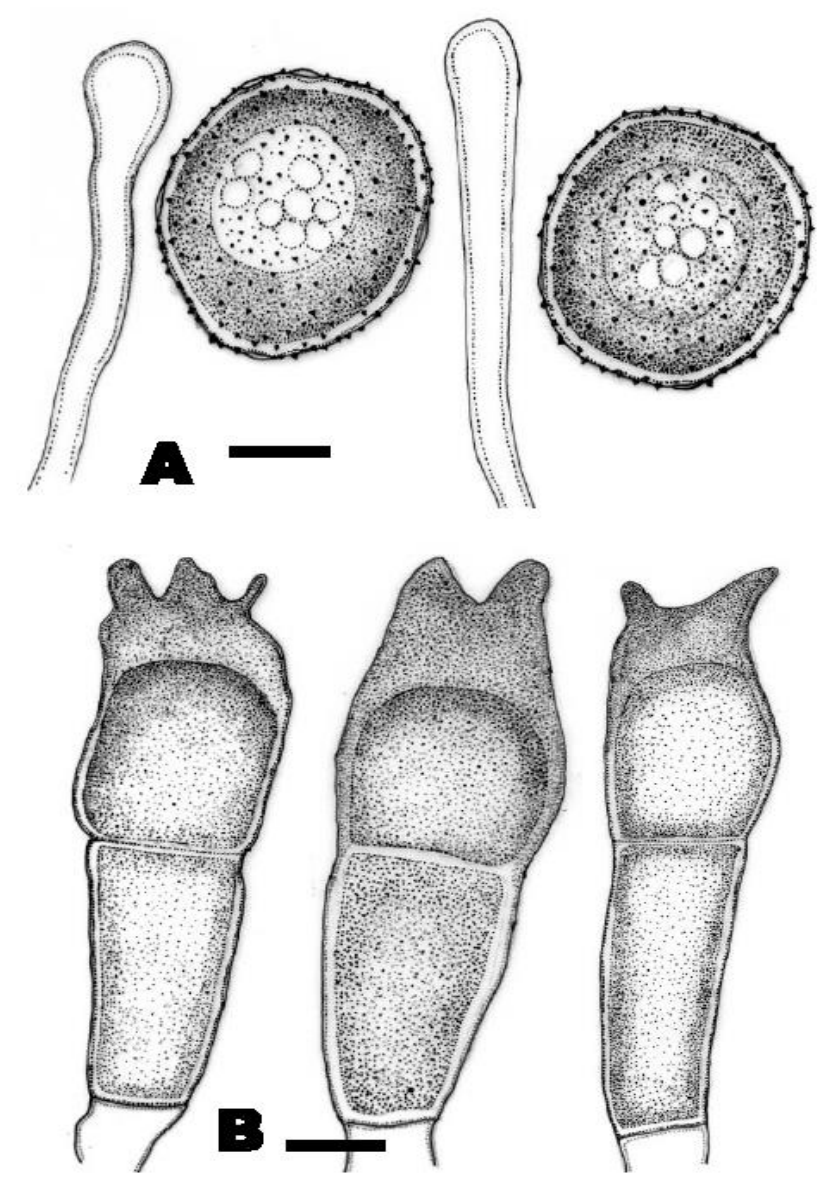

Fig. 5 - Puccinia coronate var. himalensis. A, Camera lucida drawing of echinulate urediniospores. B, Camera lucida drawing of coronate teliospores. - Bars $=10 \mu \mathrm{m}$. This picture is copyright of Najam-ul-SeharAfshan.

\section{Acknowledgements}

This work was financed by the Higher Education Commission of Pakistan (HEC) and we are highly obliged for support.

\section{References}


Abbasi SH. 1993 - Vegetation analysis with special reference to deforestation in Kaghan Valley. M.Sc. Thesis, Department of Botany, Govt. Postgraduate College Abbotabad, University of Peshawar.

Afshan NS, Khalid AN, Niazi AR. 2008 - New records of graminicolous rust fungi from Pakistan. Pakistan Journal of Botany 40, 1279-1283.

Afshan NS, Khalid AN, Iqbal SH, Niazi AR. 2010 - A new anamorphic rust fungus with a new record of Uredinales from Azad Kashmir, Pakistan. Mycotaxon 112, 451-456.

Ahmad S. 1956a - Uredinales of Pakistan. Biologia 2, 29-101.

Ahmad S. 1956b - Fungi of Pakistan. Biological Society of Pakistan, Lahore Monograph, 1, 1-126.

Ahmad S. 1962 - Further contributions to the fungi of Pakistan. II. Biologia 8, 123-150.

Ahmad S. 1969 - Fungi of Pakistan, Biological Society of Pakistan, Lahore, Monograph 5, Suppl. I, $110 \mathrm{p}$.

Ahmad S, Iqbal SH, Khalid AN. 1997 - Fungi of Pakistan. Sultan Ahmad Mycological Society of Pakistan, Lahore.

Cao Z-m, Li ZQ, Zhuang JY. 2000 - Uredinales from the Qinling Mountains (continued I). Mycosystema 19, 181-192.

Champion HG, Seth SK, Khattak GM. 1965 - Forest types of Pakistan. Pakistan Forest Institute Peshawar. 238 p.

Cummins GB. 1971 - The rust fungi of cereals, grasses and bamboos. Springer Verlag, BerlinHeidelberg-New York.

Farr DF, Rossman AY. 2014 - Fungal Databases, Systematic Mycology and Microbiology Laboratory, ARS, USDA. Retrieved December 3, 2014, from http://nt.arsgrin.gov/fungaldatabases/.

Hiratsuka N, Sato S, Katsuya K, Kakishima M, Hiratsuka Y, Kaneko S, Ono Y, Sato T, Harada Y, Hiratsuka T, Nakayama K. 1992 - The rust flora of Japan. Tsukuba Shuppankai, Takezono, Ibaraki, 1205 pages.

Iqbal MS. 1986 - Revised working plan for the Kaghan reserved forests of Mansehra district, 198586 to 2004-2005. NWFP. Forest department Peshawar.

Iqbal SH, Khalid AN, Afshan NS, Niazi AR. 2008 - Rust fungi on Saccharum species from Pakistan. Mycotaxon 106, 219-226.

Liu, M, Hambleton S. 2012 - Laying the foundation for a taxonomic review of Puccinia coronatas.l. in a phylogenetic context. Mycological Progress 12, 63-89.

Malik SA, Khan MA. 1944 - Parasitic fungi of the North-West Frontier Province. Indian Journal of Agriculture Sciences 13, 522-527.

Ramachar P, Cummins GB. 1963 - The species of Uromyces on the tribe Paniceae. Mycopathol. Mycological Applications 19, 49-61.

Saba M, Khalid AN, Afshan NS. 2011 - Species of the genus Uromyces (Basidiomycota: Pucciniales) from Leepa Valley, Azad Jammu and Kashmir (AJ and K), Pakistan. African Journal of Biotechnology 10, 16480-16483.

Saba M, Niazi AR, Khalid AN. 2013 - New records of Uredinales (Basidiomycota) from Azad Jammu and Kashmir and adjacent Northern Areas of Pakistan. International Journal of Agriculture and Biology 15, 878-884.

Zhuang WY. 2005 - Fungi of northwestern China. Mycotaxon, Ltd., Ithaca, NY, 430 pages. 